\title{
Impact of Financing on Small and Medium Enterprises (SMEs) Profitability with Moderating Role of
} Islamic Finance

\author{
Saqib Muneer, Azhar Ali, ${ }^{*}$ Rao Abrar Ahmad \\ Government College University Faisalabad, Pakistan \\ saqibmuneer85@gmail.com, ${ }^{*}$ rana.azharali11@gmail.com, abrar_rao008@yahoo.com
}

\begin{abstract}
Small and medium enterprises (SMEs) are the very significant for the development of economy of the country, grasp the attention of government and policy makers in developed as well as in developing countries. SMEs in Pakistan have their vital role in economic growth. Therefore, it is essential that SMEs have right to use sources of finance. The study used the quantitative approach that was accomplished by survey questionnaires. Two hundred SMEs and seventy bank branches were selected in Faisalabad region in Pakistan, to get response on questionnaires about their financing patterns and effects of Islamic financing as moderator in their fixed assets, set up and current assets financing. The study showed that fixed assets, set up and current asset financing have positive relation with the growth of SMEs and Islamic modes of financing was not behaved as moderator in Faisalabad city in Pakistan.
\end{abstract}

Keywords: Islamic finance, Islamic modes of financing, SMEs, fixed asset, set up, current assets financing

\section{Introduction}

Small and medium enterprises are chief factor for the economic progress in the most of countries weather these are developed or developing countries (Zarook, Rahman \& Khanam, 2013; Islam, Yousuf \& Rahman, 2014; Zubair, 2014; Mohammed, 2015 a). Most of the authors such as Harvie and Lee (2002) and Beaver and Prince (2004) explained that the SMEs contribution in job creation, innovation in the market, in exports and in private sector, are very prominent in developed as well as in developing countries. In Arab countries, they increased the job opportunities, develop the skilled work force and gave choices in the market for customer at reasonable cost and also improved the quality of product by increasing competition in the market (Alwugayan and Alshimmri, 2010; Emine, 2012). As the Pakistan is also a developing country, so the role of SMEs in Pakistan is not more different from other world. SMEs sector in the Pakistan has tremendous ability to grow and having capability to make Pakistan as regional financial center. It can also make the Pakistan as trade hub for investment in private sector. But the main problem in their way of progress is limited sources of financing (Cowling et al., 2012; Dong and Men, 2014; Karadag, 2015). Kauser, Durrani, Hussain and Hasan (2012) pointed out that banks were promoting large enterprises and neglecting the small enterprises which gave rise to huge financial gap between small enterprises and large enterprises, about $75 \%$ of finance applications of small enterprises were rejected in the one year by the commercial banks. There are many researchers (Aggarwal \& Youssef, 2000; Ahmed, 2009; Ahmed, 2010; Al-Jarhi, 2013; Gheeraert, 2014; Abdelsalam \& El Komi, 2014) worked to promote the Islamic finance to provide the solution financing obstacles for SMEs. The financing of SMEs through Islamic modes put direct effect on the growth of SMEs (Imam and Kpodar, 2015, Shaban et al., 2014, WB-IDB, 2015).

The scenario in the Pakistan is not more different for SMEs financing. Mostly SMEs are encountered with lack of collateral for loan and asymmetric information which hinders the financing institution to lend money. To encounter these problem, there should be need to encourage the Islamic financing in Pakistan for SMEs to get finance at easy conditions (Mohammad et al., 2007). Due to the lack of the literature in Islamic finance and commercial finance, relation between them to support the SMEs and also scarce literature to support the importance of Islamic finance for SMEs specifically in Pakistan, it is very essential and timely to study the role of Islamic finance and SMEs growth in Pakistan (Nurul, Mahfuzur, and Mohamed, 2014). Faisalabad is considered one of the main cities in Pakistan for business and also known as Manchester of Pakistan because of majority of industries is in this city, especially it is consider as hub of textile industry. So, SMEs in Faisalabad are studied for this paper. The contribution of this research is to go to check the impact of financing through Islamic financing on the growth of SMEs. 


\section{Literature Review}

The business sector of the world has two major parts, one is public sector and other is small and medium enterprises (SMEs) sector. The most significant thing is that the SMEs have been reflecting the major contribution in the development of this world for many years. The World Bank defines SMEs using the following indices (Ayyagari et al., 2005; Ardic et al., 2011):

- Micro enterprise: number of employ 10 ,assests having the worth of $\$ 100,000$ and sale are up to $\$ 100,000$

- Small enterprises having about 50 employees, assets and sales are about $\$ 3$ million.

- Medium enterprises contain 300employes, having assets and sales up to $\$ 15 \mathrm{million}$.

Major parts of economic prosperity in developed and developing countries are due to SMEs (Sadi \& Henderson, 2010; Muneer \& Rehman, 2012). SMEs is the factor of job creation, it provided about 51\% of new jobs and have share about 22\% of GDP in Saudi Arabia (Mohammed, 2015 b).There are about 60-70\% of employment is based on SMEs sector in OECD countries (OECD, 2006). SMEs are not only giving the jobs but also are the sources of producing innovating things which fulfill the needs of society appropriately (OECD, 2006; Sadi \& Henderson, 2010; Shaban et al., 2014). SMEs are also source of innovation and flexibility in the market which gathered more value in developed as well as developing countries (Al-Disi, 2010; Zeitouni, 2012; Karadage, 2015). According to the business statistics of 2013 in European Union countries almost all companies were SMEs. Especially it captured the manufacturer market up to 95\% in most of countries. 99.9\% in Turkey, 80\% in United States manufacturers are SMEs (OECD, 2005). Beck \& Kunt (2006), Cowling et al. (2012) accounted that there are 4 million SMEs in United Kingdom and making the $46 \%$ of private sector employment.

By analyzing the value of SMEs in world, Pakistan has also observed the importance of this sector for economic development. In 1972, the government of Zulifiqar Ali Bhutto introduced the concept of SMEs in Pakistan. Small business Finance Corporation (SBFC) was come into being by the section of parliament act 1972, to support the small enterprises to establish cottage industry. Due to bad practices and corruption, SBFC was amalgamated into in SMEs bank limited in January 2002 (SMEs bank, 2009). In January 2002, two other institutions were merged into SMEs Bank limited which was regional development finance corporation (RDFC) and Small Business Finance Corporation (SBFC). The state bank of Pakistan defined SMEs as:

"A small Enterprise (SE) is a business entity which having the at most fifty employees and (including contract employees) and annual sales turnover limit is up to Rs.150 million. Small Enterprises can be enhanced finances up to Rs.25 Million. Medium Enterprise (ME) is a business entity, ideally not a public limited company which having the employment limit is 50 to 100 employees (including contract employees).The employment standard in case of manufacturing \& service establishments is between 50 to 250 employees (including contract employees). For all MEs annual sales turnover is over Rs.150 million and up to Rs.800 million. Medium Enterprises can be extended finances over Rs.25 Million to Rs.200 Million" (SBP, 2010)

The participation of SMEs in Pakistan is very imperative; it contributes $90 \%$ of business. It provides the labor force (Non-Agriculture) about $80 \%, 25 \%$ of export, 35\% manufacturing business and most valuable contribution in GDP which is almost 30\% (Economic Survey, 2009-10). The most of loaning for SMEs by financial institution in are in Punjab, which are $90 \%$ of total loan portfolio of SMEs. This ratio in Sind is 25.93\%, 10\% in Khyber Paktukawan, Gilgitbaltistan, Baloshitan, Azad Jammu and Kashmir (SBP, 2009). The literature explains not only the importance of SMEs sector but also highlights the obstacles facing by SMEs in the world. The financing obstacle is very frequent and prominent problems for SMEs (OECD, 2006). Getting the source of finance is the main hurdle in growth of SMEs (Cowling et al., 2012; Dong and Men, 2014; Karadag, 2015). Beck and Kunt (2006) are also of this mind that the main cause of failure of this sector is not find the source of finance because of some reasons such as SMEs do not bear more risk, asymmetric information, high cost of small services transaction and low production. This is also explained in the studies of authors such as Beck et al. (2006), Beck et al. (2011), Cowling et al. (2012), and Shaban et al. (2014) Islam et al. (2014). Like the other countries, In Pakistan, mostly SMEs also encounter with lack of collateral for loan and asymmetric information which hinders the financing institution to lend money. There are many other reasons such as lack of accounting information, low ability to earn more profit level, high liquidity and many 
more performance criteria for loan proposal (ISPB, 2005).Pakistan is developing country so SMEs also encounter here with lack of capital, miss management and lack of skills and marketing policies (SBP, 2009). So, SMEs financing is most valuable in Pakistan. Appropriate financing of fixed assets, set up and current assets can up lift the growth rate of small firms. SMEs planning and control is affected by fixed assets financing. Fixed assets are the source of collateral when debts are granted by any financial institutions (Vatavu, 2012). Fixed assets financing have positive relationship with profitability of firm (La Rocca et al., 2011). Beside fixed assets financing, the next important activity for SMEs is to build up the set up for business activities. The newly start business needs finance to arrange the mechanism for the business operations So, the finance that is used for making set up of the business is known as set up financing. Shaban et al. (2014) showed the significant relationship between set up financing and SMEs profitability. To run the routine business activities, firm needs the current assets. The short term assets usually less than one year are categorized as current assets. Lazridis and Tryfonidis (2006) announced that current assets management has importance especially in small firms in both developed and developing countries. Mathuva (2009) showed that there is significant relationship between SMEs profitability and current assets financing.

Figure 1: Theoretical Frame Work

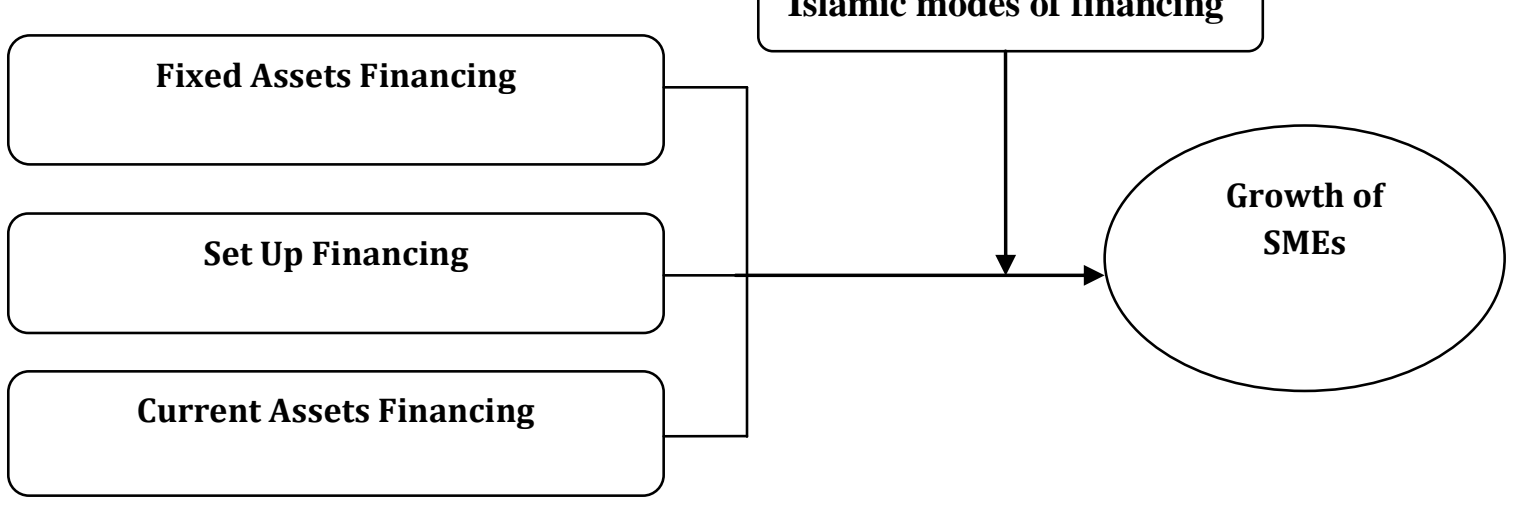

But a lot of literature has showed that SMEs faced many obstacles in financing through conventional means (Steijvers et al., 2010; Rocha et al., 2011; Vasilenko \& Arbaciauskas, 2012; Zubair, 2014). Many researchers (Khan \& Bhatti, 2008; Aggarwal \& Youssef, 2000; Ahmed, 2009; Ahmed, 2010; Abdelsalam \& El-komi, 2014; Ernst \& Young 2014; Naceur, Barajas, Massara, 2015) support the Islamic financing because it increase the growth rate in double digit and now a days it is most growing sector of economy. Islamic banking and financing has very great importance in Pakistan in gearing up the growth of SMEs. It was started from 1977 to 1978 with an effort to make the interest free commercial bank in Pakistan. To check the impact of financing of variables (fixed assets, set up and current assets) and role of Islamic finance as moderator, the following hypothesis are developed:

\section{Hypothesis 1:}

H1: fixed assets financing is positively related to profitability of SMEs.

H1a: fixed assets financing is not positively related to profitability of SMEs.

\section{Hypothesis 2:}

H2: set up financing is positively related to profitability of SMEs.

$\mathrm{H} 2 \mathrm{a}$ : set up financing is not positively related to profitability of SMEs.

\section{Hypothesis 3:}

H3: current assets financing is positively related to profitability of SMEs.

H3a: current assets financing is not positively related to profitability of SMEs.

\section{Hypothesis 4:}

H4: Islamic modes of financing acts as a moderator is affecting on the profitability of SMEs.

H4a: Islamic modes of financing acts as a moderator is not affecting the profitability of SMEs 


\section{Methodology}

The research has been carried to develop the awareness about Islamic modes of financing which are used by Small and Medium Enterprises. This study is conducted to test hypothesis and to develop a relationship between the dependent variable "Small and Medium Enterprises growth" and the independent variables "fixed assets financing, setup financing, current assets financing" with moderating effect of Islamic finance. Survey questionnaires are used to collect the response from the target population. The population is specified as all the Small and Medium Enterprises and banks in Faisalabad city. The sample for this study is comprised of 200 SMEs and 70 banks branches operating within the geographical territory of Faisalabad. A total of two hundred and seventy questionnaires were delivered to the small and medium enterprises and banks, out of which one hundred and ninety seven responses were received back. During data entry, 10 questionnaires were incomplete and considered as redundant. Remaining 187 questionnaires were considered for the analysis. The feedback rate of the existing study is fine to characterize the population. To test the hypothesis, Structural Equation Modeling (SEM) is applied by using partial least square (PLS, 3.02).

\section{Results}

For the data analysis in SEM, it is necessary that the data should be reliable. "Reliability is the instrument's ability to fabricate similar outcomes over the period of time" (Bonds-Raacke and Rackee, 2012). Reliability is measured in this study by using standard Cronbach's Alpha (1951).The benchmark value for Cronbach's Alpha reliability is 0.5 . The given table shows the Cronbach's Alpha values collectively and separately variables one by one.

Table 1: Reliability Assessment

\begin{tabular}{lll}
\hline & \multicolumn{2}{l}{ Cronbach's Alpha Items } \\
\hline Overall Reliability & .898 & 19 \\
Fixed Asset Financing & .614 & 2 \\
Set Up Financing & .629 & 2 \\
Current Asset Financing & .679 & 2 \\
Islamic Modes Of Financing & .644 & 5 \\
Growth Of SMEs & .860 & 10 \\
\hline
\end{tabular}

In this research, the firm performance is linked with the four variables. First is fixed assets financing, second one is set up financing, third one is current asset financing and the last variable is Islamic mode financing which is used as moderator. The model values show the contribution of each factor in assessing the firm performance. Fixed assets financing, set up financing and current asset financing contributes $(0.351),(0.314)$, $(0.232)$ and these variables define the firm performance about $(0.586)$ is shown by fig \#2. It indicates that the more factors are also effects the firm performance. The values of $\mathrm{t}$ - statistics and $\mathrm{R} 2$ showed in table indicate that the whole model is significant.

\section{Figure 2: Predictive Relevance of Structure}

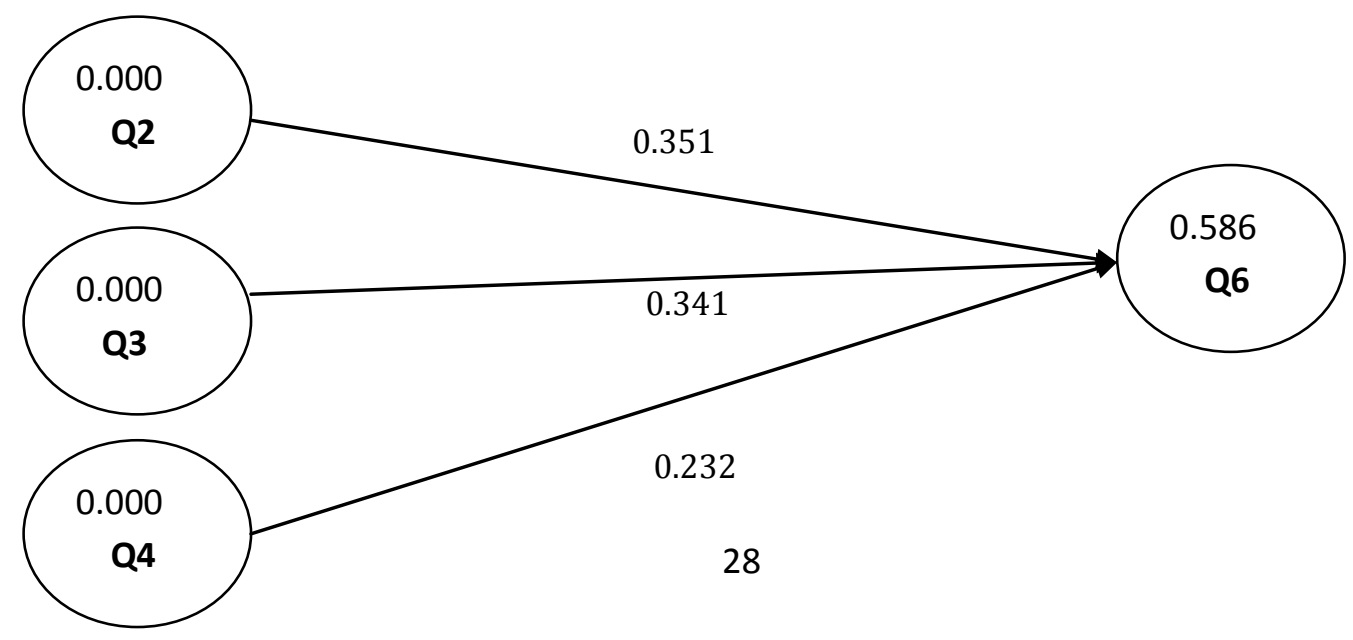


Note: Q2 (fixed assets financing), Q3 (set up financing), Q4 (current assets financing), Q6 (firm performance)

Table 2: Model Summery

\begin{tabular}{|c|c|c|c|c|}
\hline $\begin{array}{l}\text { Hypothetical } \\
\text { Relationship }\end{array}$ & Path Coefficient & $\begin{array}{l}\text { Absolute } \\
\text { statistic value }\end{array}$ & $\begin{array}{ll}t- & \text { Value of R2 }\end{array}$ & Value of Q2 \\
\hline $\mathrm{Q} 2-\mathrm{Q6}$ & $0.351^{* * *}$ & 6.945 & & \\
\hline Q3-Q6 & $0.314^{* * *}$ & 5.599 & & \\
\hline Q4-Q6 & $0.232^{* * *}$ & 4.426 & & \\
\hline Q6 & & & 0.586 & 0.261 \\
\hline
\end{tabular}

The Islamic modes of financing are acting as moderator in this study. When Islamic modes of financing is taken as an independent variable (IV) to check its impact on firm performance and its shows (Q5=.637) of firm performance which is good of total firm performance. The value of R2 is significant because it should be more than .5 Cronbach's (1951). But the impact of Islamic modes of financing (Q5) with fixed asset financing (Q2) is shown the combined effect up to $69.2 \%$ on firm performance (Q6) with path values fixed assets financing (Q2) is 0.290 and Islamic modes of financing (Q5) is 0.638 . The multiplicative path coefficient value of fixed assets financing and Islamic modes of financing $\left(Q^{*}{ }^{*} 5\right)$ is -0.019 which is very low and it showed that Islamic modes of financing may be behaved as an independent variable, have some impact of firm performance but not working as a moderator which is illustrated in following figure \#3 and model summary.

Figure 3: Predictive Relevance of Structure for moderator

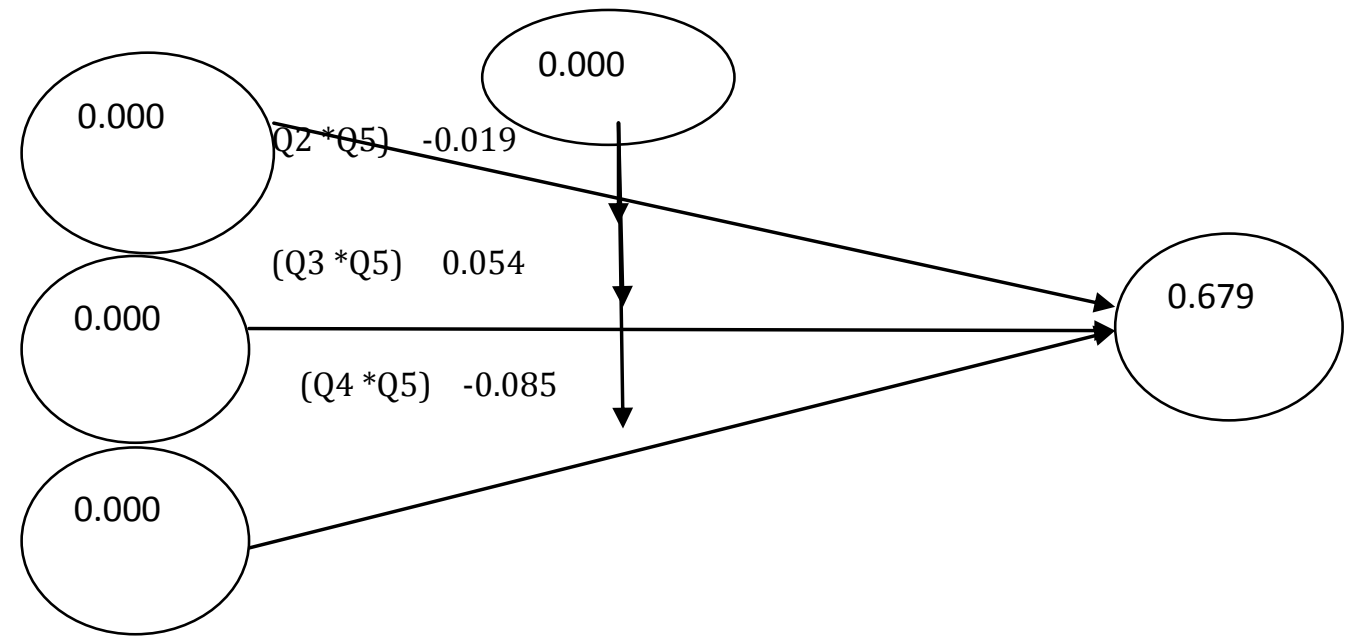

Note: Q2 (fixed assets financing), Q3 (set up financing), Q4 (current assets financing), Q5 (Islamic modes of financing), Q6 (firm performance)

Table 3: Model Summery

\begin{tabular}{|c|c|c|c|c|}
\hline $\begin{array}{l}\text { Hypothetical } \\
\text { Relationship }\end{array}$ & Path Coefficient & $\begin{array}{l}\text { Absolute } \\
\text { statistic value }\end{array}$ & $t-\quad$ Value of R2 & Value of Q2 \\
\hline Q2-Q5 & -0.019 & 0.192 & & \\
\hline Q6 & & & 0.692 & Not moderator \\
\hline Q3-Q5 & 0.054 & 0.724 & & \\
\hline Q6 & & & 0.679 & Not moderator \\
\hline Q4-Q5 & -0.085 & 0.957 & 0.661 & Not moderator \\
\hline
\end{tabular}

Secondly, the relation between Islamic modes of finance (Q5) and set up financing (Q3) is examined on the financial performance of SMEs (Q6). Both of the parameters (Q3) and (Q5) have combined $67.9 \%$ impact on SMEs performance $(Q 6)$ with having path values $(Q 3=.264)$ and $(Q 5=.601)$. Multiplicative path coefficient value of set up financing and Islamic modes of financing $\left(Q^{*}{ }^{2} 5\right)$ is 0.054 which is very low as shown in figure\#3 and table\#3.Its mean that Islamic modes of financing $(Q=5)$ is also not worked as a moderator in this 
relation. Next ,the parameters Islamic modes of financing (Q5) and current asset financing (Q4) have shown collectively $66.1 \%$ impact on firm growth (Q6) and have path values (Q4=.207) and (Q5=.714). Path coefficient value of Islamic modes of financing and current assets financing (Q4*Q5) is -0.085 which is significantly low, as given above figure\#3 and table. It shows that Islamic modes of financing $(Q=5)$ is not worked as a moderator and not effecting the relationships between independent (IV) and dependent variable (DV) significantly.

\section{Conclusion}

The data analysis of the study shows that the SMEs which are financing their fixed assets through Islamic finance the observed $69.2 \%$ contribution in profitability. The analysis also reveals that mostly $10 \%$ to $20 \%$ SMEs are using Islamic finance to finance their fixed assets. It also examined the majority of the SMEs are used Islamic financing to finance their vehicles to reduce their operational and carriage cost.25\% Ijara financing and $18 \%$ musharka financing instrument are used for this purpose. The fixed assets financing through Islamic modes is significantly positive relation with profitability of SMEs. In Pakistan, if SMEs use the Islamic mode to finance then they will show more growth as compared to ordinary method of finance and for this the most suitable instrument are Ijara and Musharaka to use. SMEs which are financing their set up cost through Islamic finance the observed $67.9 \%$ contribution in profitability. $20 \%$ to $30 \%$ SMEs are using Islamic finance to finance their set up financing.38.6\% mudarbah financing and18.4\% musharka financings instrument are used for this purpose. Therefore, it is concluded that SMEs with more set up financing affects more the growth rate. The set up financing through Islamic modes is significantly positive relation with profitability of SMEs and for this the most suitable instrument used are mudarbah and Musharaka.

The data analysis of the study also shows that the SMEs which are financing their current assets through Islamic finance the observed $66.1 \%$ contribution in profitability. 10 to.20\% SMEs are using Islamic finance to finance their current assets. It also examined that it is preferable for SMEs to use Islamic financing for finance their current assets to reduce their operational cost. 33.3\% murabaha financing, $21.5 \%$ istisna financing instrument and 18.8\% musharka financing instrument are used for this purpose. Therefore, it is concluded that SMEs with more current assets financing affects more the growth rate. The current assets financing through Islamic modes is significantly positive relation with profitability of SMEs and for this the most suitable instrument used are murabaha and Musharaka and istisnah. The second objective of the present study was to examine the behavior of Islamic modes of financing as moderate the relationship between fixed assets, set up, current asset financing and profitability of SMEs in Faisalabad Pakistan. But Islamic finance might be worked as a moderator in any other economy but not worked in Faisalabad due to have insignificant values of variables as the product of Islamic finance, in Pakistan. This study also explains that Islamic financing work as an independent variable that have some affect on profitability of SMEs.

Limitations of the Research Study: Regardless of high ambition, the study is limited by low resources, both financial and non-financial resources. Because of limitation of time and finance, scope of the researcher became confined into some specific areas and forced to study limited but important aspect of the SMEs sector. Moreover the research problem and questions are linked many fields of research problem but the time and finance constrain prohibits the researcher to study all the areas of research problems. Because of limited access to scare resources, this study could not research SMEs in all regions of Pakistan. The selected SMEs located in Faisalabad city took as the target population. Moreover, there is no proper knowledge about the SMEs sector in Pakistan. The literature on SMEs which are using Islamic finance to finance their activities are very rear and relation of these activities with performance is also very less. Limited legislation about the SMEs financing is the another problem in Pakistan.

Suggestions for Future Research: This study was designed to examine relationships between Islamic modes of financing and SMEs profitability. Its limitations were explained above are suggest further research to expand areas that could not be captured in this research. Additional implications of this study for the further research could include the following:

- Findings on Islamic modes of financing could be used as the basis for specific and detailed research into every separate aspect of financial practices in Pakistan 
- The model of SME profitability developed in this study could be applied as the basis for the further research on building competitive strategies for SMEs.

- This model can checked in other cities of Pakistan to check the influence the Islamic financial practices.

- Government support for the SME sector is still limited to offering finance, but the study found that the government could play a significant role in supporting the SME sector. Therefore, the role of government for supporting SMEs is very healthy topic for further research.

- Results of the research have both theoretical and practical suggestion for enhancing financial management practices especially in small enterprises for expansion of this sector of Pakistan.

\section{References}

Abdelsalam, O. \& EL-Komi, M. (2014). Islamic finance: An Introduction. Journal of Economic Behavior and Organization, 2(1).

Aggarwal, R. K. \& Yousef, T. (2000). Islamic banks and investment financing. Journal of money, credit and banking, 93-120 292

Ahmed, A. (2010). Global financial crisis: an Islamic finance perspective. International Journal of Islamic and Middle Eastern Finance and Management, 3(4), 306-320.

Ahmed, S. (2009). Islamic banking finance and insurance A global overview. A.S. Noordeen.

Al-Disi, E. O. (2010). Developmental role for Waqf to support entrepreneurship and small and medium enterprises. Dubai International conference for Awqaf.

Al-jarhi, M. A. (2013). Gaps in the Theory and Practice of Islamic Economics. JKAU Islamic Econ., 26(1).

Al-Wugayan, A. \& Alshimmiri, T. (2010). Encouragement of Entrepreneurship in Affluent Economies: The Case of Kuwait. International Business \& Economics Research Journal (IBER), 9(6).

Ardic, O. P., Mylenko, N. \& Saltane, V. (2011). Small and medium enterprises: a cross-country analysis with a new data set. World Bank Policy Research Working Paper Series.

Ayyagari, M., Beck, T. \& Demirguc-Kunt, A. (2005). Small and medium enterprises across the globe. Small Business Economics, 29(4), 415-434.

Beaver, G. \& Prince, C. (2004). Management, strategy and policy in the UK small business sector: a critical review. Journal of Small Business and Enterprise Development, 11(1), 34-49

Beck, T. \& Demirgüç-Kunt, A. (2006). Small and medium-size enterprises: Access to finance as a growth constraint. J. Bank. Finance, 30(11), 2931-2943.

Beck, T., Demirgue, A. \& Peri, M. S. M. (2011). Bank financing for SMEs: Evidence across countries and bank ownership types. Journal of Financial Services Research, 39(1-2), 35-54.

Bonds-Raacke, J. \& Raacke, J. (2010). My Space and Facebook: Identifying dimensions of uses and gratifications for friend networking site. Individual Differences Research, 8(1), 27-33

Cowling, M., Liu, W. \& Ledger, A. (2012). Small business financing in the UK before and during the current financial crisis. International Small Business Journal, 30(7), 778-800

Cronbach, L. J. (1951). Coefficient alpha and the internal structure of tests. Psychometrika, 16.

Dong, Y. \& Men, C. (2014). SME Financing in Emerging Markets: Firm Characteristics, Banking Structure and Institutions. Emerging Markets Finance and Trade, 50(1), 120-149.

Emine, D. (2012). Financial Challenges that impede increasing the productivity of SMEs in the Arab region.

Ernst \&Young. (2014). The World Islamic Competitiveness Report.2014-2015.

Gheeraert, L. (2014). Does Islamic finance spur banking sector development? Journal of Economic Behavior \& Organization, 4(2).

Harvie, C. \& Lee, B. C. (2002). East Asian SMEs: Contemporary Issues and Developments-An Overview. The role of SMEs in national economies in East Asia, 1-9.

Imam, P. A. \& Kpodar, K. (2015). Is Islamic Banking Good for Growth? IMF Working Papers.

Islam, M. A., Yousuf, S. \& Rahman, M. I. (2014). SME Financing in Bangladesh: A Comparative Analysis of Conventional and Islamic Banks. Journal of Islamic Banking and Finance, 2(1), 79-92.

Investigation of Banker's Lending Criteria to SMEs and Assessment There off 297-334.

Karadag, H. (2015). Financial Management Challenges In Small And Medium-Sized Enterprises: A Strategic Management Approach. EMAJ: Emerging Markets Journal, 5(1), 26-40

Khan, M. M. \& Bhatti, M. I. (2008). Islamic banking and finance: On its way to globalization. Managerial Finance, $34(10), 708-725$. 
La Rocca, M., La Rocca, T. \& Cariola, A. (2011). Capital structure decisions during a firm's life cycle. Small Business Economics, 37(1), 107-130. Doi:10.1007/s11187-009-9229-z

Lazaridis, I. \& Tryfonidis, D. (2006). Relationship between working capital management and profitability of listed companies in the Athens stock exchange. Journal of Financial Management and Analysis, 19(1), 26-35.

Mathuva, D. M. (2009). The Influence of working capital management components on corporate profitability: A survey on Kenyan Listed Firms. Research Journal of Business Management, 4(1), 1 - 11.

Mohammad, H. K. (2007). A Shari'ah Analysis of Issues in Islamic Leasing. J.KAU: Islamic Econ., 20(1), 3-22

Mohammed, A. Q. (2015 a). Talent Attraction and Retention in Saudi Arabian Family Owned Small and Medium Scale Enterprises (SME's). Journal of Business Management \& Social Sciences Research, 4(2), 182-189.

Mohammed, A. Q. (2015 b). Employee recruitment, selection and retention in Saudi Arabian family owned Small and Medium Scale Enterprises (SMEs) Kuwait Chapter of Arabian. Journal of Business and Management Review, 4(6).

Muneer, S. \& Rehman, S. U. (2012). Materialization of Behavioral Finance and Behavioral Portfolio Theory: A Brief Review. Journal of Economics and Behavioral Studies, 4(8), 431-435

Naceur, S. B., Barajas, A. \& Massara, A. (2015). Can Islamic Banking Increase Financial Inclusion? No.15-81

Nurul, M. M. (2014). Issues and Prospects of Islamic Hire Purchase Financing: Malaysian Evidence. Journal of Management Research, 6(1).

OECD. (2006). Financing SMEs and Entrepreneurs 2006

Rocha, R. D. R., Farazi, S., Khouri, R. \& Pearce, D. (2011). The status of bank lending to SMEs in the Middle East and North Africa region: The results of a joint survey of the Union of Arab Banks and the World Bank. World Bank Policy Research Working Paper Series.

Sadi, M. A. \& Henderson, J. C. (2010). Franchising and small medium-sized enterprises (SMEs) in industrializing economies: A Saudi Arabian perspective. Journal of Management Development, 30(4), 402-412.

Shaban, M., Duygun, M., Anwar, M. \& Akbar, B. (2014). Diversification and banks' willingness to lend to small businesses: Evidence from Islamic and conventional banks in Indonesia.

Steijvers, T., Voordeckers, W. \& Vanhoof, K. (2010).Collateral, relationship lending and family firms. Small Business Economics, 34(3), 243-259.

Vasilenko, L. \& Arbačiauskas, V. (2012).Obstacles and drivers for sustainable innovation development and implementation in small and medium sized enterprises. Environmental Research, Engineering and Management, 60(2), 58-66.

Vatavu, S. (2012). Trade-off versus pecking order theory in listed companies around the world. Annals of the University of Petrosani Economics, 12(2), 285-292.

World Bank, Islamic Development Bank, Islamic Research and Training Institute, 2015d. Leveraging Islamic finance for SMEs. Joint WB-IDB Policy Report.

Zeitouni, I.Q. (2012). The role of Waqf in Funding Small project. Journal specialized in Waqf \& Charitable Activities, Kuwait Waqf Public Foundation.

Zubair, A. K. I. (2014). Entrepreneurship and Economic Development in Nigeria: Evidence from Small and Medium Scale Enterprises (SMEs) Financing. 